Acta vet. scand. $1969,10,36-43$.

From the Department of Medicine II, Royal Veterinary College, Stockholm, Sweden.

\title{
STUDIES ON PARTURIENT PARESIS WITH SPECIAL REFERENCE TO THE DOWNER COW SYNDROME
}

By

K.-A. Björsell, P. Holtenius and S. O. Jacobsson

In addition to the classic form of parturient paresis characterized by hypocalcemia and somnolence, which responds rapidly to calcium therapy, it is not unusual to encounter other forms of this disease. The most common aberration would seem to be that in which the animals do not rise after calcium treatment. Many of these cows show little or no drowsiness, their appetite is often good, and the results of a clinical examination often negative. Some authors, Blood \& Henderson (1960) for instance, consider that this "downer cow syndrome" is an independant disease not connected wiht milk fever.

Although the downer cow syndrome is a common disease and is of considerable significance, remarkably little has been written about it. Garm in 1950 noted that the frequency of downers had increased as compared with the numbers registered a few years earlier. He had also noticed that in many of these cows hypocalcemia was present on the first day of illness but not on subsequent days, despite the fact that they had marked signs of milk fever. Osinga, in an investigation in 1963, compared two types of milk fever: a typical form in which the cow is drowsy, lies on her side, and has partial anorexia, and an atypical form in which the animal is alert and has normal or only slight loss of appetite. Osinga remarked that the atypical cases had in- 
creased in number and suggested as an explanation the fact that the amount of protein in the fodder has increased, with the result that auto-intoxication and damage to parenchymatous organs may occur.

The object of the present investigation was to study the difference between cows that recover after treatment ("uncomplicated milk fever") and those that have not risen $24 \mathrm{hrs}$. after the first treatment ("downers"). We also wanted to ascertain whether any changes occurred in the downers between the first and second, and second and third days. In addition, the difference between cows with blood-calcium levels equivalent to or over $8.0 \mathrm{mg} / 100 \mathrm{ml}$ serum and those with corresponding values under $8.0 \mathrm{mg}$ at the first examination was also studied.

\section{MATERIAL AND METHODS}

The investigation included 283 cows that had developed milk fever in the Fjärdhundra veterinary district in central Sweden during the period March 1, 1964 - May 31, 1966. All the cows were of the Swedish red and white breed.

A general clinical examination was carried out at each visit and the findings were recorded. Blood samples were drawn in connection with the examination and were sent to the Department of Clinical Chemistry at the Veterinary College, arriving there as a rule on the following day.

The serum calcium was measured with a Perkin-Elmer model 202 atomic absorption spectro-photometer. Glutamic oxaloacetic transaminase (GOT) was determined by the method of Reitman $\&$ Frankel (1957) and total serum protein by the method described by Weichselbaum (1946). The serum protein fractions were separated by paper electrophoresis using the apparatus described by Valmet $\&$ Svensson (1954) and the Tris-borate-buffer method of Aronsson \& Grönwall (1957). Amido black was used for the staining of the proteins and a Beckman-Spinco Analytrol for the determination of the protein fractions. The material has been statistically analyzed; conventional statistical methods and symbols are used.

All the cows were given calcium at the first visit, after the blood samples had been drawn. Most of them were also given calcium after the blood sampling at the second visit. At subsequent visits, calcium therapy was not given in those cases in 
T a ble 1. Calcium, GOT, total protein and albumin/globulin ratio in cows with uncomplicated milk fever and in downers. Calcium given in $\mathrm{mg} / 100 \mathrm{ml}$ serum, GOT in Karmen units, and total protein in $\mathrm{g} / 100 \mathrm{ml}$.

\begin{tabular}{|c|c|c|c|c|c|c|c|c|c|c|c|c|c|}
\hline \multirow{2}{*}{ Group } & \multirow{2}{*}{ Visit } & \multicolumn{3}{|c|}{ Calcium } & \multicolumn{3}{|c|}{ GOT } & \multicolumn{3}{|c|}{ Total protein } & \multicolumn{3}{|c|}{ Alb./glob. } \\
\hline & & $\mathbf{n}$ & $\overline{\mathrm{x}}$ & $\Sigma_{\mathrm{x}}$ & $\mathbf{n}$ & $\overline{\mathbf{x}}$ & $\Sigma \overline{\mathrm{x}}$ & $\mathbf{n}$ & $\bar{x}$ & $\Sigma \bar{x}$ & $\mathbf{n}$ & $\overline{\mathbf{x}}$ & $\Sigma_{\mathbf{x}}^{-}$ \\
\hline $\begin{array}{l}\text { Cows with } \\
\text { uncomplicated } \\
\text { milk fever }\end{array}$ & 1 & 184 & 6.0 & 0.15 & 179 & 161 & 16 & 104 & 7.20 & 0.08 & 108 & 1.45 & 0.02 \\
\hline \multirow[t]{3}{*}{ Downers } & 1 & 99 & 5.9 & 0.21 & 77 & 167 & 16 & 46 & 7.33 & 0.18 & 46 & 1.33 & 0.06 \\
\hline & 2 & 80 & 7.3 & 0.24 & 77 & $33^{*} 6$ & 47 & 46 & 7.12 & 0.09 & 46 & 1.31 & 0.06 \\
\hline & 3 & 29 & 8.9 & 0.35 & 29 & $8 \stackrel{* *}{1}$ & 115 & 18 & 7.14 & 0.18 & 18 & 1.23 & 0.10 \\
\hline
\end{tabular}

*) denotes almost significant $(\mathrm{P}<0.05)$

$\left.{ }^{\star *}\right)$ denotes significant $(\mathrm{P}<0.01)$

$\star \star *)$ denotes a highly significant difference $(\mathrm{P}<0.001)$

which the clinical examination and the blood tests from the previous visit indicated that hypocalcemia was no longer present and that complications - muscle damage, for instance - had arisen from that condition.

\section{RESULTS}

Tables 1 and 2 show the results of the laboratory studies. Of the 283 cows, $184(65 \%)$ recovered after the first visit. The other $99(35 \%)$ became downers and required further treatment; 29 of them had to be slaughtered.

Of the 184 cows with uncomplicated milk fever, $27(13.5 \%)$ already had blood calcium values of $8 \mathrm{mg} / 100 \mathrm{ml}$ serum or over initially. In the group of downers, 14 out of 99 cows $(14 \%)$ had a calcium level of $8 \mathrm{mg}$ or over at the first examination.

At the first clinical and blood chemistry examination, no definite difference was found between the cows with uncomplicated milk fever and those that became downers. For the blood calcium, the mean values were $6.0 \mathrm{mg}$ and $5.9 \mathrm{mg} / 100 \mathrm{ml}$, respectively, and for the total protein in the blood the mean values were $7.20 \mathrm{~g}$ and $7.33 \mathrm{~g} / 100 \mathrm{ml}$ serum, respectively. The values for glutamic oxaloacetic transaminase (GOT) were 161 and 167 units, respectively.

A comparison between the values obtained at the first examination and those from the second revealed that definite changes 
$\mathrm{T}$ a b l e 2. GOT, total protein and albumin/globulin ratio in serum in cows with an initial serum calcium concentration under 8.0 or $8.0 \mathrm{mg} / 100 \mathrm{ml}$ serum and over. GOT given in Karmen units and total protein in $\mathrm{g} / 100 \mathrm{ml}$ serum.

\begin{tabular}{|c|c|c|c|c|c|c|c|c|c|c|}
\hline \multirow{2}{*}{ Group } & \multirow{2}{*}{ Visit } & \multicolumn{3}{|c|}{ GOT } & \multicolumn{3}{|c|}{ Total protein } & \multicolumn{3}{|c|}{ Alb./glob. } \\
\hline & & $\mathbf{n}$ & $\overline{\mathbf{x}}$ & $\Sigma \bar{x}$ & $\mathbf{n}$ & $\overline{\mathbf{x}}$ & $\Sigma_{\mathrm{x}}$ & $\mathbf{n}$ & $\overline{\mathbf{x}}$ & $\Sigma_{\mathrm{x}}^{-}$ \\
\hline $\begin{array}{l}\text { Cows with un- } \\
\text { complicated } \\
\text { milk fever and } \\
\text { Ca }>8.0 \\
\text { initially }\end{array}$ & 1 & 26 & 176 & 25 & 12 & 6.97 & 0.12 & 12 & 1.32 & 0.09 \\
\hline $\begin{array}{l}\text { Cows with un- } \\
\text { complicated } \\
\text { milk fever and } \\
\text { Ca }<8.0 \\
\text { initially }\end{array}$ & 1 & 153 & 158 & 18 & 92 & 7.23 & 0.09 & 95 & 1.48 & 0.05 \\
\hline \multirow{2}{*}{$\begin{array}{l}\text { Downers with } \\
\text { Ca > 8.0 } \\
\text { initially }\end{array}$} & 1 & 12 & 179 & 38 & 6 & 7.42 & 0.40 & 6 & 1.25 & 0.17 \\
\hline & 2 & 12 & 336 & 47 & 6 & 7.38 & 0.22 & 6 & 1.25 & 0.19 \\
\hline \multirow{2}{*}{$\begin{array}{l}\text { Downers with } \\
\text { Ca }<8.0 \\
\text { initially }\end{array}$} & 1 & 65 & 163 & 18 & 40 & 7.32 & 0.20 & 40 & 1.34 & 0.07 \\
\hline & 2 & 65 & $\begin{array}{l}\star \star \star \star \\
490\end{array}$ & 55 & 40 & $\begin{array}{c}\star \star \star \star \\
7.08 \\
\end{array}$ & 0.10 & 40 & 1.31 & 0.06 \\
\hline \multirow{2}{*}{$\begin{array}{l}\text { Downers with } \\
\text { muscle damage } \\
\text { confirmed at } \\
\text { necropsy }\end{array}$} & 1 & 15 & 263 & 61 & - & - & - & - & - & 一 \\
\hline & $\begin{array}{l}2 \\
3\end{array}$ & $\begin{array}{r}12 \\
9\end{array}$ & $\begin{array}{r}788 \\
1588\end{array}$ & $\begin{array}{l}162 \\
156\end{array}$ & - & - & 二 & - & 二 & 二 \\
\hline
\end{tabular}

*) denotes almost significant $(P<0.05)$

**) denotes significant $(P<0.01)$

$\star \star \star)$ denotes highly significant difference $(\mathrm{P}<0.001)$

had occurred in the downer group. The mean value for the blood calcium had risen from 5.9 to $7.3 \mathrm{mg} / 100 \mathrm{ml}$ and the GOT value from 167 to 336 units. The total protein level in the serum had fallen from 7.33 to $7.12 \mathrm{~g} / 100 \mathrm{ml}(\mathrm{P}<0.01)$. At the third examination, the mean value for the blood calcium was $8.9 \mathrm{mg}$ and the GOT value was 841 units; in other words considerable increases had occurred as compared with the values at the second examination. The total protein level on the other hand had not changed significantly.

When each of the two groups was divided into two sub-groups according to the initial blood calcium level, no significant dif- 
ferences were apparent with respect to GOT, total protein level, and albumin-globulin ratio (Table 2) between the animals in the four sub-groups. The fall in the total protein level in blood serum that was noted in the downers between the first and second examinations seems to have been confined to the hypocalcemia group.

\section{DISCUSSION}

The investigation revealed nothing to suggest that the disease pattern in the downers differed at the outset from that of the cows with milk fever that recovered after one treatment. The results indicated that, as Pehrson (1967) and Jönsson \& Pehrson (1968) have already pointed out, the downer cow syndrome is a complication of an ordinary parturient paresis. One cause is of course that the blood calcium level did not return to normal after one treatment. Fifty-seven $\%$ of the cows had a blood calcium level below $8 \mathrm{mg} / 100 \mathrm{ml}$ at the second examination. The effect of a treatment is naturally of short duration, and it is necessary for recovery that the uptake of the calcium via the fodder and its resorption and mobilization should function normally. Impaired appetite and digestive disturbances, for example, can obstruct the possibility of a return to a normal blood calcium level.

Marr et al. (1955) studied the blood calcium level before and after treatment in cows with milk fever. Following an increase immediately after the injection the values then decreased and $10 \mathrm{hrs}$. later had fallen to approximately the same level as before the treatment; the cows that had risen and had no clinical signs of paresis also showed the same pattern. There were no appreciable differences between these cows and those that did not rise, with respect to the blood calcium level after treatment. In the cows that showed clinical recovery, the blood calcium level then rose gradually and was normal three or four days later. Cows that were still down were treated again, and the concentration of calcium in the blood first rose rapidly, then fell, and finally rose again to the normal level.

The total protein level in the blood showed a fall between the first and second examinations in the downer group. This change was only observed in the hypocalcemia group, however; in the animals with a normal calcium concentration no significant 
changes occurred. The lowered blood protein level probably had some connection with deficient nutrition. It is difficult to decide whether the hypocalcemia was the cause of the impaired assimilation of food, or vice versa. In all probability, it was a question of a combination of both factors.

The complications of milk fever take different forms, and may affect muscles, nerves or bones. The strikingly increased GOT values suggest that muscle damage was present. The high GOT values could also have been caused by liver damage. Gould \& Grimes (1960) found increased GOT values in downers, and suspected that the cause was fatty change of the liver. Infiltration of fat into the liver is common in puerperal diseases. Such infiltration caused only a slight rise in the GOT values in serum, however (Holtenius \& Jacobsson 1966). The increased GOT concentration observed in the present investigation was probably connected with muscle damage. Muscle tears and haemorrhages, mainly in the thigh muscles, were found in the slaughtered animals. In an investigation at present in progress, assays are being made not only of GOT but also of ornithine carbamyl transferase (OCT) and creatine phosphokinase (CPK); this will make it possible to distinguish between muscle and liver damage.

The height of the GOT level at the outset and the gradually increasing values with the length of time the cow was down indicate that the nature of the muscle damage is traumatic, not nutritional muscular dystrophy. In this disease the GOT level is many times higher. Oksanen et al. found no cases of nutritional muscular dystrophy among 209 cows with milk fever investigated in 1964.

It is not clear whether the muscle damage and consequent GOT increases are mainly the result of pressure because the cow remains lying down, or whether they are caused by muscle tears when she makes efforts to rise. The necropsy findings in the slaughtered cows showed that muscle tears are not uncommon. Probably, it is in many cases a question of a combination of muscle tears and the pressure factor.

Complications leading to the downer cow syndrome can to a certain extent be avoided by maintaining nutrition at as satisfactory a level as possible, and by seeing that the cow has sufficient space and that there is no risk of slippery floors. 


\section{REFERENCES}

Aronsson, T. \& A. Grönwall: Improved separation of serum proteins in paper electrophoresis - a new electrophoresis buffer. Scand. J. clin. Lab. Invest. 1957, 9, 338.

Blood, D. C. \& J. A. Henderson: Veterinary Medicine, London 1960.

Garm, O.: Unders $\varnothing$ kelser over paresis puerperalis, paraplegia ante partum, eclampsia puerperalis og gresstetani hos ku. (Studies on paresis puerperalis, paraplegia antepartum, eclampsia puerperalis and grass tetany in cows). Nord. Vet.-Med. 1950, 2, $751-764$.

Gould, C. M. \& F. C. Grimes: Milk fever. Vet. Rec. 1960, 72, 338-340.

Holtenius, P. \& S.-O. Jacobsson: Ornithine-carbamyl-transferase (OCT) activity in ruminants. Cornell Vet. 1966, 56, 187-195.

Jönsson, G. \& B. Pehrson: Något om diagnostisering av muskelskador hos långliggare. (On diagnosing muscle damages in downers). Svensk Vet.-Tid. 1968, 20, 5-6.

Marr, A., E. W. Moodie \& A. Robertson: Some biochemical and clinical aspects of milk fever. J. comp. Path. 1955, 65, 347-365.

Oksanen, H. E., G. Nordström \& L. Bryne: Undersökning rörande förekomst av vaxartad muskeldegeneration hos paretiska kor i Uppsala veterinärdistrikt. (A study of the occurrence of muscle degeneration in paretic cows in the Uppsala veterinary district). Svensk Vet.-Tidn. 1964, 16, 324-326.

Osinga, A.: Diet and the clinical picture of milk fever. T. Diergeneesk. $1963,88,147-153$.

Pehrson, B.: Kalvningsförlamning - kan den förebyggas? (Parturient paresis — can it be prevented). Foderjournalen 1967, 3, 64-68.

Reitman, S. \& S. Frankel: A colorimetric method for the determination of serum glutamic oxalacetic and glutamic puruvic transami. nasis. Amer. J. clin. Path. 1957, 28, 56.

Valmet, E. \& H. Svensson: Some problems inherent in paper electrophoresis. The LKB paper electrophoresis apparatus. Science Tools 1954, 1, 3 .

Weichselbaum, T.E.: An accurate and rapid method for determination of proteins in small amounts of blood serum and plasma. Amer. J. clin. Path. tech. Sect. 1946, 10, 40.

\section{SUMMARY}

A group of 283 cows with parturient paresis were studied. Of these animals, 184 , or $65 \%$ recovered after one treatment. The other 99 cows became downers and needed further treatment. At the clinical examination and blood chemistry assay in connection with the first visit no difference was demonstrated between cows with uncomplicated milk fever and cows that did not rise. A comparison between the findings at the first and second examinations showed definite changes in the downer group. The mean value for the blood calcium 
had risen from 5.9 to $7.3 \mathrm{mg}$, and the GOT level from 167 to 336 units. At the third examination, the blood calcium had risen to $8.9 \mathrm{mg}$ and the GOT to 841 units.

The results suggest that the downer cow syndrome is a complication of milk fever, and that muscle damage is a common explanation of why the cows remain downers.

\section{ZUSAMMENFASSUNG}

\section{Studien über Gebärparese in specieller Ansehung des Festlieger- komplexes.}

Die Untersuchungen umfassen 283 Rinder mit Gebärparese. Davon genasen 184 oder $65 \%$ nach einer Behandlung. Die übrigen 99 wurden zu Festliegern und beanspruchten weitere Behandlung. Mit klinischen und blutchemischen Analysen konnte bei der ersten Untersuchung zwischen den Rindern, die an unkomplizierter Gebärparese litten und denen, die zu Festliegern wurden, kein Unterschied gefunden werden. Beim Vergleich zwischen der ersten und der zweiten Untersuchung der Festliegergruppe konnte man deutliche Veränderungen feststellen. Der Mittelwert von Blutkalk war von 5,9 bis 7,3 und der GOT-Wert von 167 bis 336 angestiegen. Bei der dritten Untersuchung lag der Kalkwert bei 8,9 und der GOT-Wert bei 841 .

Die Untersuchungsresultate sprechen dafür, dass das Festliegerkomplex eine Komplikation der Gebärparese ist, und dass die Muskelschäden die gewöhnliche Ursache dafür sind, dass die Rinder zu Festliegern werden.

\section{SAMMANFATTNING}

Undersökningar över paresis puerperalis med speciell hänsyn till lảngliggarkomplexet.

Undersökningen omfattar 283 kor med paresis puerperalis. Av dessa tillfrisknade 184 eller $65 \%$ efter en behandling. De övriga 99 blev långliggare och krävde ytterligare behandling. Vid klinisk och blodkemisk undersökning vid första undersökningstillfället kunde ingen skillnad påvisas mellan de kor som led av okomplicerad paresis puerperalis och de som blev långliggare. Vid jämförelse mellan förhållandena vid första undersökningstillfället och vid det andra hos långliggargruppen kunde tydliga ändringar påvisas. Medelvärdet för blodkalcium hade stigit från 5,9 till 7,3. GOT-värdet hade stigit från 167 till 336. Till tredje undersökningstillfället hade blodkalciumvärdet stigit till 8,9 och GOT till 841 .

Undersökningsresultaten talar för att långliggarkomplexet är en komplikation till paresis puerperalis, och att muskelskador är en vanlig orsak till att korna blir långliggare. 